\title{
KAJIAN YURIDIS ATAS PROSES SERTIFIKAT HAK ATAS TANAH WAKAF YANG BERSTATUS LETTER C DI KANTOR PERTANAHAN KABUPATEN SEMARANG
}

\author{
Raden Ari Setya Wibawa \\ Magister Hukum Universitas Semarang, Semarang
}

\begin{abstract}
ABSTRAK
Tujuan penelitian ini adalah untuk mengkaji dan menganalisa proses sertifikat tanah atas tanah wakaf. Wakaf adalah perbuatan hukum wakif untuk memisahkan dan/atau menyerahkan sebagai harta benda miliknya untuk dimanfaatkan selamanya atau untuk jangka waktu tertentu sesuai dengan kepentingannya guna keperluan ibadah dan/atau kesejahteraan umum menurut syariah. Pelaksaan perwakafan di Indonesia sangat sederhana, cukup ditandai oleh rasa kepercayaan dan terpenuhinya beberapa syarat tertentu sesuai ajaran hukum islam. Cukup diikrarkan dihadapan nadzir dan saksi, maka telah dianggap selesai pada pencatatan desa saja. Sebagai akibatnya sering tidak ada usaha pengadministrasian resmi pada instasi berwenang, sehinga tidak adanya kepastian hukum didalamnya. Metode penelitian yang digunakan dalam penelitian ini menggunakan pendekatan yuridis normatif, dengan spesifikasi deskriptif analitis. Hasil penelitian menunjukkan bahwa : 1) pelaksanaan perwakafan tanah masih tetap mengacu pada peraturan perundang-undangan mengenai perwakafan tanah yang terdahulu. Dengan diberlakukannya UndangUndang Nomor 41 Tahun 2004 tentang wakaf, mengenai wakaf untuk benda tidak bergerak yang dalam hal ini adalah tanah, dilakukan berdasarkan dan berpedoman pada Peraturan Menteri Agraria dan Tata Ruang/BPN Nomor 2 Tahun 2017. 2) Fungsi tanah Wakaf itu harus dipergunakan untuk sosial, keagamaan dan Kemanusiaan. 3) status tanah masih pertanian harus dilakukan ijin perubahan penggunaan tanah (IPPT) terlebih duhulu apabila akan didirikan bangunan dan harus sesuai dengan tata ruang.
\end{abstract}

Kata kunci : Wakaf; letter C; sertifikat tanah 
e-ISSN : 2621-4105

\title{
JURIDIC STUDY ON THE PROCESS OF CERTIFICATE OF THE RIGHT TO LANDTER LAND WAKAF STATUS IN THE LAND OFFICE OF SEMARANG REGENCY
}

\author{
Raden Ari Setya Wibawa \\ Master of Law, University of Semarang, Semarang
}

\begin{abstract}
The purpose of this study is to study and analyze the process of land certificate over waqf land. Waqf is a legal at of wakif to separate and or surrender as him property to be used forever or for a certain period in accordance with their interests for the purposes of worship and or general welfare according to sharia. The implementation of waqf in indonesia is very simple, quite marked by certain beliefs and conditions in accodance with islamic teachings. It wa sufficiently promised before nadzir and witnesses that it was considered finished only in the village records. As a result there is often no attempt to formally manage the authorized institution, so there is no legal certainty.Research methods used in this study using normative juridical approach, the analytical descriptive specification. The results showed that: 1) The implementation of land ownership still refers to the legislation regarding the previous land ownership. With the enactment of law number forty one year two thousand four concerning waqf, regarding waqf for immovable objects which in this case is land, is based on and based on the regulation of the minister of Agraria dan Tata ruang/BPN number two years two thousand seventeen. 2)the function of the waqf land must be used for social, religious and humanitarian purposes. 3)the status of the land is stiil agricultural, a permit must be changed in advance if the building is to be built and must be in accordance with the spatial plan.
\end{abstract}

Keywords: waqqf; letter C; land cerificate 
e-ISSN : 2621-4105

\section{A. PENDAhuluan}

Allah menciptakan langit dan bumi untuk manusia dan diamanatkan kepada manusia sebagai khalifah dimuka bumi. Tanah yang merupakan salah satu bagian dari bumi mempunyai hubungan yang erat dengan kehidupan manusia. Bahkan dapat dikatakan setiap manusia berhubungan dengan tanah, tidak hanya pada masa hidupnya tetapi sesudah meninggalpun masih tetap berhubungan dengan tanah. Oleh sebab itu tanah merupakan suatu kebutuhan yang paling penting dalam kehidupan dunia ini. ${ }^{1}$

Bagi sebagian rakyat Indonesia, tanah menempati kedudukan sangat penting dalam kehidupan sehari-hari. Sebagai warga Negara Indonesia yang baik, seseorang di tuntut melakukan sesuatu menurut ketentuan hukum yang berlaku. Demikian juga dengan urusan kekayaan atau kepemilikan lainnya seperti tanah harus dilakukan pencatatan agar kelak dikemudian hari tidak menimbulkan suatu sengketa.

Di Indonesia masalah pertanahan memperoleh kedudukan yang penting. Penggunaan dan pemanfaatan tanah untuk kesejahteraan masyarakat tertuang dalam pasal 33 ayat (3) UUD’45 dan Amandemen, yang berbunyi :

"Bumi, air dan kekayaan alam yang terkandung didalamnya dikuasai oleh Negara dan dipergunakan sebesar-besarnya untuk kemakmuran rakyat."

Pengaturan tentang pertanahan tersebut selanjutnya diatur dalam UndangUndang No. 5 Tahun 1960 tentang Peraturan Dasar Pokok Agraria yang lebih dikenal dengan Undang-Undang Pokok Agraria.

Perwakafan tanah saat ini sebelum diatur dalam Hukum Agraria Nasional. Pelaksanan wakaf masih sangat sederhana yaitu cukup ditandai oleh adanya rasa kepercayaan dan terpenuhinya beberapa unsur dan syarat tertentu sesuai dengan ajaran hukum Islam, yaitu cukup diikrarkan di hadapan nadzir serta disaksikan oleh beberapa orang saksi. Sebagai akibatnya, sering tidak ada usaha pengadministrasian

\footnotetext{
${ }^{1}$ Mudjiono, Politik Hukum Agraria, Cet. 1 (Yogyakarta, Liberty, 1977), hlm.19
} 
sama sekali atau hanya sampai pencatatan ke desa saja, tidak sampai pada instansi yang berwenang terhadap masalah pertanahan. ${ }^{2}$

Sangat erat kaitannya dengan pemanfaatan tanah untuk kesejahteraan umum, salah satunya adalah penggunaan tanah wakaf. Wakaf merupakan hukum Islam yang diseluruh Indonesia telah diterima masyarakat karena mayoritas penduduk Indonesia adalah penganut Agama Islam. Meskipun Indonesia mengakui dan menjalankan hukum positif, namun bangsa Indonesia realitanya juga membutuhkan tuntunan dan peraturan dari hukum Islam. Karena dalam perkembangan hukum di Indonesia mengacu pada nilai-nilai ajaran Islam yang disesuaikan dengan budaya dan tradisi bangsa Indonesia, yang salah satunya adalah masalah perwakafan. ${ }^{3}$

Di dalam praktik pelaksanaan perwakafan tanah ini sebelum diatur dalam Hukum Agraria Nasional, pelaksanaannya sangat sederhana yaitu cukup ditandai oleh adanya rasa kepercayaan dan terpenuhinya beberapa unsur dan syarat tertentu sesuai dengan ajaran hukum Islam saja. Melalui cukup diikrarkan di hadapan nadzir serta disaksikan oleh beberapa orang saksi, maka telah dianggap selesailah pelaksanaan wakaf tersebut. Sebagai akibatnya, sering tidak ada usaha pengadministrasiannya sama sekali atau hanya sampai pencatatan ke desa saja, tidak sampai pada instansi yang berwenang terhadap masalah pertanahan.

Pelaksanaan perwakafan seperti tersebut di atas, memang lebih mudah karena tidak ada prosedur dan tata cara yang rumit dan berbelit-belit. Akan tetapi sebagai akibatnya hal tersebut tidak menjamin kelestarian dan kesinambungan pengelolaan wakaf dari generasi ke generasi berikutnya secara tertib, yang disebabkan oleh tidak dilindunginya perwakafan tanah tersebut dengan suatu alat bukti yang kuat atau dengan kata lain belum terdapat adanya kepastian hukum didalamnya.

Akibat yang sering ditimbulkan dengan tidak diaturnya secara tegas dan tuntas masalah perwakafan tanah tersebut, yaitu memudahkan timbulnya penyimpangan dan penyelewengan dari hakekat dan tujuan wakaf itu sendiri, misalnya dengan

${ }^{2}$ Lambang Prasetyo, Kedudukan Hukum Pengambilalihan Tanah Wakaf Yang Batal Demi Hukum Untuk Dibagikan Sebagai Harta Warisan Dalam Kajian Undang-Undang No. 41 Tahun 2004 Tentang Wakaf, Jurnal Ius Constituendum Vol 2 No 1, Magister Hukum Universitas Semarang, 2017 Semarang, hlm.79. DOI: http://dx.doi.org/10.26623/jic.v2i1.545 
banyaknya timbul persengketaan-persengketaan yang terjadi karena adanya perubahan status atau peruntukkan wakaf, seperti Tanah wakaf dipergunakan untuk sosial, kegamaan dan kemanusiaan, tetapi kenyataanya di lapangan masih ada yang digunakan untuk komersil. Dikabulkan atau ditolaknya pensertipikatan tanah wakaf saat di tinjau fungsi atau pemanfaatannya ke lapang. Apakah sesuai atau tidak sesuai dengan ketentuan yang berlaku. Apabila status tanah masih pertanian harus dilakukan ijin perubahan penggunaan tanah (IPPT) terlebih duhulu apabila akan didirikan bangun dan harus sesuai dengan tata ruang.

\section{B. PERMASALAHAN}

1. Bagaimana Praktek Pensertipikatan Hak Atas Tanah Wakaf yang Berstatus Letter C di Kantor Pertanahan Kabupaten Semarang?

2. Bagaimana Kendala dan Solusi Pensertipikatan Hak Atas Wakaf yang Berstatus Letter C di Kantor Pertanahan Kabupaten Semarang?

\section{METODE PENELITIAN}

Dalam penelitian tentang "Kajian Yuridis Atas Pensertipikatan Hak Atas Wakaf yang Berstatus Letter C" ini metode penelitian hukum normatif yang sering kali disebut juga dengan penelitian hukum doktrinal biasanya hanya menggunakan atau bersarana pada sumber data sekunder saja yakni peraturan perundang-undangan, keputusan-keputusan pengadilan, teori-teori maupun konsep hukum. ${ }^{4}$

\section{Metode Pendekatan}

Pendekatan masalah dalam penelitian ini adalah pendekatan yuridis normatif yaitu pendekatan yang dilakukan berdasarkan bahan hukum utama dengan cara menelaah teori-teori, konsep-konsep, asas-asas hukum serta peraturan perundangundangan yang berhubungan dengan penelitian ini. Pendekatan ini dikenal pula

${ }^{3}$ Dept. Agama RI, Pedoman Pengelolaan dan Pengembangan Wakaf (Jakarta : Direktorat Bimbingan Masyarakat Islam dan Penyelenggaraan Haji, 2003), hlm.48

${ }^{4}$ Suratman dan Philips Dillah, Metode Penelitian Hukum, (Bandung : Alfabeta, 2013), hlm. 11 
dengan pendekatan kepustakaan yakni dengan mempelajari buku-buku, peraturan perundang-undangan dan dokumen lain yang berhubungan dengan penelitian ini. ${ }^{5}$

2. Spesifikasi Penelitian

Penulis menggunakan penelitian yang bersifat deskritif analitis, deskriptif analitis adalah metode pengumpulan data dan fakta melalui interprestasi yang tepat. Penelitian ini menggambarkan tentang bagaimana Kajian Yuridis Atas Pensertipikatan Hak Atas Wakaf yang Berstatus Letter C..

Adapun yang disebut metode deskriptif analitis menurut para ahli adalah metode yang bertujuan mendeskripsikan atau memberi gambaran terhadap obyek penelitian yang diteliti melalui sampel atau data yang telah terkumpul dan membuat kesimpulan yang berlaku umum. ${ }^{6}$

3. Sumber dan Jenis Data

Sumber dan jenis data yang dipakai dalam penelitian ini adalah data sekunder, yang mencakup bahan hukum primer dan bahan hukum sekunder. ${ }^{7}$

a. Bahan-bahan hukum primer yang digunakan adalah sebagai berikut :

1) Undang-undang Nomor 41 Tahun 2004 Tentang Wakaf

2) Peraturan Pemerintah Republik Indonesia Nomor 42 Tahun 2006 Tentang Pelaksanaan Undang-undang Nomor 41 Tahun 2004 Tentang Wakaf

3) Undang-Undang Pokok Agraria Nomor 5 Tahun1960 Tentang Peraturan Dasar Pokok-Pokok Agraria

b. Bahan hukum sekunder yaitu bahan yang terdiri dari literatur dan hasil karya ilmiah, kepustakaan yang ada hbungannya dengan Pendaftaran Pensertipikatan Hak Atas Wakaf yang Berstatus Letter C.

4. Metode Pengumpulan data

a. Studi Kepustakaan

${ }^{5}$ Amiruddin dan ainal Asikin, Pengantar Metode Penelitian Hukum, (Jakarta : PT. Raja Grafindo Persada, 2003), hlm.166 2009)

${ }^{6}$ Soegiono, Metode Penelitian Kuantitatif, Kualitatif dan $R \& D$, (Bandung : Alfabeta,

${ }^{7}$ Ronny Hanitijo Soemitro, Metode Penelitian Hukum dan Jurimetri, (Jakarta : Ghalilea Indonesia, 1990) hlm.11 
Metode pengumpulan data yang ditempuh dalam penelitian ini adalah studi kepustakaan, yakni penelitian terhadap berbagai data sekunder yang berkaitan dengan penelitian. ${ }^{8}$

b. Wawancara

Wawancara adalah cara untuk memperoleh suatu informasi dengan bertanya langsung pada yang diwawancarai. Dalam hal ini peneliti akan bertatap muka langsung dengan nara sumber yang berkaitan dengan permasalahan dalam tesis ini.

5. Metode Analisa Data

Metode analisa data yang digunakan adalah analisa data kualitatif yang bertujuan menggambarkan secara sistematik dan akurat mengenai fakta tentang populasi kasus tertentu. ${ }^{9}$ Data dianalisa isinya dengan menggunakan asas-asas hukum, teori-teori hukum, dan peraturan perundang-undangan yang ada, yang kemudian disusun dalam bentuk laporan.

\section{PEMBAHASAN}

\section{Praktek Pensertipikatan Hak Atas Tanah Wakaf yang Berstatus Letter C di} Kantor Pertanahan Kabupaten Semarang

Dengan diberlakukannya Undang-Undang Nomor 41 Tahun 2004 tentang wakaf, ketentuan dalam Pasal 16 ayat (1) huruf a dan ayat (2) yaitu ketentuan mengenai wakaf untuk benda tidak bergerak yang dalam hal ini adalah tanah, dilakukan berdasarkan dan beredoman pada Peratura Menteri Agraria dan Tata Ruang/Badan Pertanahan Nasional Nomor 2 Tahun 2017, yaitu sebagai berikut:

Pasal 1

Dalam Peraturan Menteri ini yang dimaksud dengan:

1. Wakaf adalah perbuatan hukum wakif untuk memisahkan dan/atau menyerahkan sebagian harta benda miliknya untuk dimanfaatkan selamanya atau untuk jangka waktu tertentu sesuai dengan kepentingannya guna keperluan ibadah dan/atau kesejahteraan umum menurut syariah.

${ }^{8}$ Soegiono, Op Cit. hlm.52

${ }^{9}$ Suharsimi Arikunto, Analisa Data Dalam Penelitian, (Surabaya : Rineka Cipta, 2006), hlm 21 
2. Wakif adalah pihak yang mewakafkan harta benda miliknya.

3. Nazhir adalah pihak yang menerima harta benda Wakaf dari Wakif untuk dikelola dan dikembangkan sesuai dengan peruntukannya.

4. Akta Ikrar Wakaf yang selanjutnya disingkat AIW adalah bukti pernyataan kehendak Wakif untuk mewakafkan harta benda miliknya guna dikelola Nazhir sesuai dengan peruntukan harta benda Wakaf yang dituangkan dalam bentuk akta.

5. Akta Pengganti Akta Ikrar Wakaf yang selanjutnya disingkat APAIW adalah akta pengganti dalam hal perbuatan Wakaf belum dituangkan dalam AIW sedangkan perbuatan Wakaf sudah diketahui berdasarkan berbagai petunjuk (qarinah) dan 2 (dua) orang saksi serta AIW tidak mungkin dibuat karena Wakif sudah meninggal dunia atau tidak diketahui lagi keberadaannya.

6. Pejabat Pembuat Akta Ikrar Wakaf yang selanjutnya disingkat PPAIW adalah pejabat berwenang yang ditetapkan oleh Menteri untuk membuat Akta Ikrar Wakaf.

7. Sertipikat Tanah Wakaf adalah surat tanda bukti Tanah Wakaf.

8. Kantor Pertanahan adalah instansi vertikal Badan Pertanahan Nasional di Kabupaten/Kota yang berada di bawah dan bertanggung jawab langsung kepada Menteri melalui Kepala Kantor Wilayah Badan Pertanahan Nasional.

Pasal 2

(1) Hak atas Tanah yang telah diwakafkan hapus sejak tanggal Ikrar Wakaf dan statusnya menjadi benda Wakaf.

(2) PPAIW atas nama Nazhir menyampaikan AIW atau APAIW dan dokumendokumen lainnya yang diperlukan untuk pendaftaran Tanah Wakaf atas nama Nazhir kepada Kantor Pertanahan, dalam jangka waktu paling lama 30 (tiga puluh) hari sejak penandatanganan AIW atau APAIW.

Pasal 3

(1) Tanah yang diwakafkan dapat berupa:

a. Hak Milik atau Tanah Milik Adat yang belum terdaftar; 
b. Hak Guna Usaha, Hak Guna Bangunan dan Hak Pakai di atas Tanah Negara;

c. Hak Guna Bangunan atau Hak Pakai di atas tanah Hak Pengelolaan atau Hak Milik;

d. Hak Milik atas Satuan Rumah Susun; dan

e. Tanah Negara.

(2) Tanah sebagaimana dimaksud pada ayat (1) dapat diwakafkan untuk jangka waktu selama-lamanya, kecuali tanah sebagaimana dimaksud pada ayat (1) huruf c dan huruf d.

(3) Dalam hal tanah Hak Guna Bangunan atau Hak Pakai di atas tanah Hak Pengelolaan atau Hak Milik sebagaimana dimaksud pada ayat (1) huruf c akan diwakafkan untuk selama-lamanya, harus terlebih dahulu memperoleh izin tertulis/pelepasan dari pemegang Hak Pengelolaan atau Hak Milik.

Pasal 4

(1) Dalam hal Tanah Wakaf berupa Hak Milik sebagaimana dimaksud dalam Pasal 3 ayat (1) huruf a akan diwakafkan hanya sebagian dari luas keseluruhan, terlebih dahulu dilakukan pengukuran untuk pemisahan sertipikat tersebut.

(2) Pemisahan sertipikat sebagaimana dimaksud pada ayat (1) dibuatkan AIW atau APAIW, dan menjadi dasar untuk diterbitkan Sertipikat Tanah Wakaf atas nama Nazhir.

Pasal 5

Dalam hal sertipikat Hak Guna Usaha, Hak Guna Bangunan dan Hak Pakai di atas tanah Negara sebagaimana dimaksud dalam Pasal 3 ayat (1) huruf b terdapat catatan mengenai izin apabila akan dialihkan, untuk dapat diwakafkan harus mendapat izin terlebih dahulu dari pejabat yang berwenang.

Pasal 6

(1) Tanah Wakaf berupa Hak Milik didaftarkan menjadi Tanah Wakaf atas nama Nazhir.

(2) Permohonan pendaftaran Wakaf atas bidang tanah sebagaimana dimaksud pada ayat (1), dilampiri dengan:

a. surat permohonan; 
b. surat ukur;

c. sertipikat Hak Milik yang bersangkutan;

d. AIW atau APAIW;

e. surat pengesahan Nazhir yang bersangkutan dari instansi yang menyelenggarakan urusan agama tingkat kecamatan; dan

f. surat pernyataan dari Nazhir bahwa tanahnya tidak dalam sengketa, perkara, sita dan tidak dijaminkan.

(3) Kepala Kantor Pertanahan menerbitkan Sertipikat Tanah Wakaf atas nama Nazhir, dan mencatat dalam Buku Tanah dan sertipikat Hak atas Tanah pada kolom yang telah disediakan, dengan kalimat:

"Hak atas Tanah ini hapus berdasarkan Akta Ikrar Wakaf/Akta Pengganti Akta Ikrar Wakaf tanggal... Nomor... dan diterbitkan Sertipikat Tanah Wakaf Nomor.../... sesuai Surat Ukur tanggal... Nomor... luas... m²".

Pasal 7

(1) Tanah Wakaf yang berasal dari Tanah Milik Adat didaftarkan menjadi Tanah Wakaf atas nama Nazhir.

(2) Permohonan pendaftaran Wakaf atas bidang tanah sebagaimana dimaksud pada ayat (1), dilampiri dengan:

a. surat permohonan;

b. Peta Bidang Tanah/Surat Ukur;

c. bukti kepemilikan tanah yang sah;

d. AIW atau APAIW;

e. surat pengesahan Nazhir yang bersangkutan dari instansi yang menyelenggarakan urusan agama tingkat kecamatan; dan

f. surat pernyataan dari Nazhir/Wakif atau surat keterangan dari Kepala Desa/Lurah/tokoh masyarakat bahwa tanahnya tidak dalam sengketa, perkara, sita dan tidak dijaminkan.

(3) Dalam hal permohonan pendaftaran sebagaimana tersebut ayat (2) telah memenuhi persyaratan sesuai dengan ketentuan peraturan perundangundangan, Kepala Kantor Pertanahan menerbitkan keputusan penegasan sebagai Tanah Wakaf atas nama Nazhir. 
(4) Keputusan penegasan sebagai Tanah Wakaf atas nama Nazhir sebagaimana dimaksud pada ayat (3) dibuat sesuai dengan format tercantum dalam Lampiran I yang merupakan bagian tidak terpisahkan dari Peraturan Menteri ini.

(5) Berdasarkan keputusan sebagaimana dimaksud pada ayat (3) Kepala Kantor Pertanahan menerbitkan Sertipikat Tanah Wakaf atas nama Nazhir.

Adapun prosedur dan persyaratan yang harus dilengkapi oleh pemohon untuk pensertipikatan tanah wakaf dari tanah yang belum bersertipikat di wilayah satuan kerja Kantor Pertanahan Kabupaten Semarang, Yaitu :

1. Formulir permohonan yang sudah diisi dan ditanda tangani oleh pemohon atau kuasanya di atas materai cukup;

2. Surat kuasa apabila dikuasakan;

3. Fotocopy identitas pemohon / nadzir dan kuasa apabila dikuasakan, yang telah dicocokkan dengan aslinya oleh petugas loket;

4. Bukti pemilikan tanah / alas hak milik adat / bekas milik adat;

5. Akta ikrar wakaf / surat ikrar wakaf;

6. Fotocopy SPPT PBB tahun berjalan yang telah dicocokkan dengan aslinya oleh petugas loket;

7. Melampirkan bukti SSP/PPh sesuai dengan ketentuan.

Ada dua jenis pensertipikatan perwakafan yang dilakukan oleh pemohon yaitu pensertipikatan tanah wakaf yang diatasnamakan oleh perorangan atau nadzir. Nadzir itu terdiri dari :

1. Ketua

2. Sekretaris

3. Bendahara

4. Anggota

5. Anggota

Kemudian untuk pensertipikatan perwakafan yang dilakukan atau diatas namakan oleh yayasan. Dan berdasarkan hasil wawancara dengan Bapak Suryohadi Wisnu Wardoyo, S.SIT., MM, sebagai Kepala Subseksi Penetapan Hak dan Pemberdayaan Masyarakat pada Kantor Pertanahan Kabupaten Semarang. 
Bahwa pensertipikatan perwakafan berpedoman pada aturan baru yaitu Peraturan Manteri Agraria dan Tata Ruang/Kepala Badan Pertanahan Nasional Nomor 2 Tahun 2017. Sejak diterbitkannya peraturan tersebut pensertipikatan perwakafan yang kepengurusannya melalui satu layanan, tidak ada biaya yang harus dikeluarkan oleh pemohon atau gratis di Kantor Pertanahan Kabupaten Semarang.

\section{Kendala dan Solusi Pensertipikatan Hak Atas Wakaf yang Berstatus Letter}

\section{C di Kantor Pertanahan Kabupaten Semarang}

Kendala-kendala yang dihadapi dalam pensertipikatan tanah wakaf yang berstatus letter C di Kantor Pertanahan Kabupaten Semarang berdasarkan hasil wawancara penulis dengan Bapak Suryohadi Wisnu Wardoyo, S.SIT., M.M, Kepala Sub Seksi Penetapan Hak dan Pemberdayaan Masyarakat Kantor Pertanahan Kabupaten Semarang yaitu :

a. Tanah wakaf dipergunakan untuk sosial, kegamaan dan kemanusiaan, tetapi kenyataanya di lapangan masih ada yang digunakan untuk komersil. Dikabulkan atau ditolaknya pensertipikatan tanah wakaf saat di tinjau fungsi atau pemanfaatannya ke lapang. Apakah sesuai atau tidak sesuai dengan ketentuan yang berlaku

b. Apabila status tanah masih pertanian harus dilakukan ijin perubahan penggunaan tanah (IPPT) terlebih duhulu apabila akan didirikan bangun dan harus sesuai dengan tata ruang

c. Wakif tidak cocok dengan Nadzir

Disini terjadi ketidaksesuaian kehendak antara Wakif dengan Nadzir, misalnya wakif menginginkan pergelolaan wakaf seperti ini, sedangkan pihak masyarakat menghendaki Nadzir melakukan pengelolaan dengan cara yang berbeda dengan kehendak wakif. Sehingga atas dasar hal tersebut wakif kemudian tetap menguasai bukti tertulis (surat menyurat) atas perwakafan tanah itu.

Solusi yang dilakukan dalam menaganai kendala yang ada antara lain :

a. Dari Kantor Petanahan Kabupaten Semarang melakukan Penyuluhan terlebih dahulu agar masyarakat bisa mengerti dan memahami bahwa Fungsi tanah Wakaf itu harus dipergunakan untuk sosial, keagamaan dan Kemanusiaan, sehingga bila disuatu daerah ada orang, yayasan dan atau kelompok tertentu 
yang ingin mengkomersilkan tanah wakaf tersebut, masyarakat sekitar dapat memberikan nasehat atau bahkan memberikan teguran. Dan jika ada masyarakat yang ingin mewakafkan tanahnya bisa lebih tahu, mengerti dan memahami mengenai tanah yang mereka wakafkan. Selain itu dari Kantor Pertanahan Kabupaten Semarang juga harus meninjau ke Lokasi tanah yang akan di ajukan permohonan pensertipikatan tanah wakaf terlebih dahulu agar tahu Fungsi dan Pemanfaatannya apakah sesuai atau tidak sesuai dengan ketentuan yang berlaku terutama di wilayah Kabupaten Semarang

b. Tim Panitia Ajudikasi atau yg Sering di sebut Tim Panitia A Kantor Pertanahan Kabupaten Semarang melakukan Sidang Panitia A di Kantor Desa/Kelurahan tempat tanah wakaf yang akan di ajukan untuk Pensertipikatan, dan Tim Panitia A juga melihat riwayat tanah tersebut terlebih dahulu di Buku C Desa nya, Beberapa contoh data yang harus dilakukan pengecekan oleh Tim Panitia A yaitu apakah nama yang tercantum di buku C Desa itu sesuai dengan data yang di ajukan ke Kantor Pertanahan Kabupaten Semarang atau tidak, lokasi tanah tersebut tanah Pertanian atau tanah Non Pertanian, jika tanah tersebut adalah tanah pertanian maka harus dilakukan pengecekan Tata Ruang terlebih dahulu apakah Tanah Wakaf tersebut sesuai dengan tata ruang atau tidak sesuai dengan tata ruang, setelah mengetahui hasil dari pengecekan tata ruang tersebut maka harus dilakukan Ijin Perubahan Penggunaan Tanah ( IPPT ) apabila tanah tersebut akan didirikan bangunan dan harus sesuai dengan tata ruang yang berlaku di Kabupaten Semarang.

c. Pemanfaatan dan Pemberdayaan tanah wakaf secara produktif, dan sesuai ketentuan di samping sebagai pengamanan di bidang hukum (Pensertipikatan tanah wakaf), dan juga sebagai pengamanan dalam bidang peruntukan dan pengembangannya harus juga dilakukan. Sehingga antara Perlindungan hukum dengan aspek hakikat tanah wakaf yang memiliki fungsi sosial, keagamaan, dan kemanusiaan dapat menemukan fungsinya dan akan sangat berguna sekali untuk banyak masyarakat. 
e-ISSN : 2621-4105

\section{E. PENUTUP}

Pensertipikatan Hak atas tanah Wakaf yang berstatus Letter C di Kantor Pertanahan Kabupaten Semarang, dalam pelaksanaannya mengacu pada peraturan Perundang-undangan Nomor 41 Tahun 2004 tentang Wakaf dan untuk saat ini sudah memakai ketentuan-ketentuan dalam Peraturan Menteri Agraria dan Tata Ruang / Kepala Badan Pertanahan Nasional Nomor 2 Tahun 2017. Pengelolaan tanah wakaf di Kabupaten Semarang dalam kaitannya dengan pemberdayaan ekonomi umat sebagaimana tujuan dari diberlakukannya Undang-Undang Nomor 41 Tahun 2004 tentang wakaf yaitu dipersiapkan untuk menggerakkan seluruh potensi wakaf secara produktif untuk Sosial, Keagamaan dan Kemanusiaan.

\section{DAFTAR PUSTAKA}

\section{BUKU}

Abdurrahman, 1994, Masalah Pewakafan Tanah Milik dan Kedudukan Tanah Wakaf di Negara Kita, Bandung : Citra Aditya Bakti

Adijani Al-Alabij, 1992, Perwakafan Tanah di Indonesia dalam Teori dan Praktek, Bandung : Rajawali Press

Adrian Sutedi, 2014, Peralihan Hak Atas Tanah dan Pendaftarannya, Jakarta : Sinar Grafika

Ahmad Azhar Basyir, 1987, Hukum Islam Tentang Wakaf Ijarah dan Syirkah, Bandung: Alma Arif

Amiruddin dan ainal Asikin, 2003, Pengantar Metode Penelitian Hukum, Jakarta : PT. Raja Grafindo Persada

Andy Hartanto, 2014, Karakteristik Jual Beli Tanah Yang Belum Terdaftar Hak Atas Tanahnya, Surabaya : LaksBang Justitia

Boedi Harsono, 2003, Sejarah Pembentukan Undang-Undang Pokok Agraria : Isi dan Pelaksanaan, Jakarta : Djambatan

Boedi Harsono, 2014, Undang - Undang Pokok Agraria Sejarah Penyusunan, Isi, dan Pelaksanaannya, Djakarta: Djambatan

Dept. Agama RI, 2003, Pedoman Pengelolaan dan Pengembangan Wakaf Jakarta : Direktorat Bimbingan Masyarakat Islam dan Penyelenggaraan Haji

Fiqih Sunnah buku ke-13, 1998, Bandung: PT. Alma Arif

H. Taufik Hamami, 2003, Perwakafan Tanah Dalam Politik Hukum Agraria, Jakarta : PT. Tata Nusa

Mohammad Daud Ali, 1998, Sistem Ekonomi Islam Zakat dan Wakaf, Jakarta : Universitas Indonesia Press

Mudjiono, 1977, Politik Hukum Agraria, Cet. 1, Yogyakarta : Liberty

Ronny Hanitijo Soemitro, 1990, Metode Penelitian Hukum dan Jurimetri, Jakarta : Ghalilea Indonesia 
Saroso dan ngami, 1984, Tinjauan Yuridis Tentang Perwakafan Tanah Milik,Yogyakarta : Liberty

Soegiono, 2009, Metode Penelitian Kuantitatif, Kualitatif dan R\&D, Bandung : Alfabeta.

Suharsimi Arikunto, 2006, Analisa Data Dalam Penelitian, Surabaya : Rineka Cipta.

Suparyono, 2008, Kutipan Buku Letter C sebagai Alat Bukti Untuk Memperoleh Hak Atas Tanah.

Suratman dan Philips Dillah, 2013, Metode Penelitian Hukum, Bandung : Alfabeta

Undang-Undang Nomor 41 Tahun 2004

Urip Santoso, 2005, Hukum Agraria dan Hak-hak Atas Tanah,Jakarta : Prenada Media.

\section{JURNAL}

Lambang Prasetyo, Kedudukan Hukum Pengambilalihan Tanah Wakaf Yang Batal Demi Hukum Untuk Dibagikan Sebagai Harta Warisan Dalam Kajian Undang-Undang No. 41 Tahun 2004 Tentang Wakaf, Jurnal Ius Constituendum Vol 2 No 1, Magister Hukum Universitas Semarang, 2017 Semarang, hlm.79. DOI: http://dx.doi.org/10.26623/jic.v2i1.545

\section{UNDANG-UNDANG}

Undang-Undang Nomor 41 Tahun 2004

Peraturan Pemerintah Nomor 28 Tahun 1977

\section{INTERNET}

atrbpn.go.id, standar prosedur pendaftaran pertama kali (konversi, pengakuan dan penegasan), diakses 27 agustus 2019 